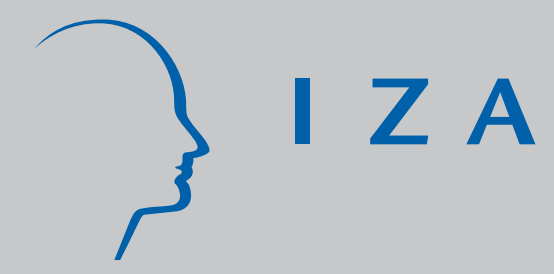

IZA DP No. 3858

On the Determinants of Pay of CEOs in UK Public Sector Higher Education Institutions

Ray Bachan

November 2008 


\title{
On the Determinants of Pay of CEOs in UK Public Sector Higher Education Institutions
}

\author{
Ray Bachan \\ University of Brighton \\ and IZA \\ Discussion Paper No. 3858 \\ November 2008 \\ IZA \\ P.O. Box 7240 \\ 53072 Bonn \\ Germany \\ Phone: +49-228-3894-0 \\ Fax: +49-228-3894-180 \\ E-mail: iza@iza.org
}

Any opinions expressed here are those of the author(s) and not those of IZA. Research published in this series may include views on policy, but the institute itself takes no institutional policy positions.

The Institute for the Study of Labor (IZA) in Bonn is a local and virtual international research center and a place of communication between science, politics and business. IZA is an independent nonprofit organization supported by Deutsche Post World Net. The center is associated with the University of Bonn and offers a stimulating research environment through its international network, workshops and conferences, data service, project support, research visits and doctoral program. IZA engages in (i) original and internationally competitive research in all fields of labor economics, (ii) development of policy concepts, and (iii) dissemination of research results and concepts to the interested public.

IZA Discussion Papers often represent preliminary work and are circulated to encourage discussion. Citation of such a paper should account for its provisional character. A revised version may be available directly from the author. 
IZA Discussion Paper No. 3858

November 2008

\section{ABSTRACT \\ On the Determinants of Pay of CEOs in UK Public Sector Higher Education Institutions ${ }^{*}$}

The pay determining process of CEOs of UK higher education institutions is modelled using three econometric methodologies applied to a large and unique dataset for the academic years 1997/98 through to 2005/06. A gender differential in pay is detected and this differential remains robust across the specifications reported and across higher education sub-sectors. There is evidence that CEOs with industrial work experience and those who have been employed by a higher education body earn more than their counterparts without these attributes. We also find that CEOs are rewarded favourably on the termination of their contracts. There is little evidence that institutional characteristics influence pay after controlling for institution fixed effects. There is only limited evidence that they are rewarded for the 'performance' of the institutions they manage, but are rewarded favourably by increasing the volume of tuition fees. There is some support for 'tournament theory' as an explanation for the determination of CEO pay in this labour market.

JEL Classification: J45, M5, M12

Keywords: CEO, pay, performance, public sector, higher education, fixed effects

Corresponding author:

Ray Bachan

Brighton Business School

University of Brighton

Brighton, BN2 4AT

United Kingdom

E-mail:rb2@bton.ac.uk

\footnotetext{
* The author would like to thank Barry Reilly, Maura Sheehan, Mike Barrow, Geraint Johnes, for their constructive comments on earlier drafts of this paper. I would also like to extend my gratitude to Penny Jones and Judy Evans for their help with the data collection. The usual disclaimer applies.
} 


\section{Introduction}

The pay awards granted to UK 'Vice Chancellors' has increasingly come under public scrutiny since 1994 when UK higher education institutions (HEIs) were required to disclose publicly the annual pay of their CEO. ${ }^{1}$ For instance in 2006, thirty three UK Vice Chancellors received an average annual salary of $£ 225,505$ and the highest paid university head earned £322,000 (Times Higher Education Supplement (THES)). Recent evidence on the national trends in the pay of CEOs of HEIs and full-time academics in the UK, between 1997 and 2006, suggests that there is a substantial difference in the level of their pay and a widening of the differential over time. The average pay of CEOs of HEIs increased by $37 \%$ in real terms over the period compared to a $13 \%$ increase received by academics, and on average the pay of CEOs of HEIs was above that of full-time academics by a factor of 3.6 over the period (ASHE, various years). These differences have been the major focus of criticism vented in the media and by lecturers' unions with the charge that the pay awards granted to CEOs of HEIs have been 'outrageous', 'shameless' and 'despicable'. However, between 2002 and 2006 the pay of CEOs that head HEIs was, on average, about $83 \%$ of the annual pay of full-time CEOs of large private sector enterprises ${ }^{3}$ and about $16 \%$ greater than the pay of senior executives. We also note that over the period CEOs of large private sector enterprises received a $23 \%$ real pay increase. Their counterparts in higher education only received a 17\% real increase (ASHE, various years).

It is argued that the leadership and managerial skills needed to lead and run large complex HEIs are similar to the executive skills needed to manage and lead large private sector companies (Dolton and Ma, 2003; Farnham and Jones, 1998; Bargh et al. 2000). In this sense the pay awards granted to CEOs of HEIs in the UK can be seen as justified and not excessive on the basis that their remuneration should be

\footnotetext{
1 'CEO' will be used as a generic term to describe all heads of UK higher education institutions (unless otherwise stated) encompassing: Vice Chancellors; Principals; Rectors; Directors and Provosts.

${ }^{2}$ See for example the following articles published in THES: 'Large rises at top as pay dispute grips sector (10 ${ }^{\text {th }}$ March 2006); ' $25 \%$ wage hike for v-cs' (10 $0^{\text {th }}$ March 2006); 'Heads enjoy $100 \%$ rise in pay over ten years' $\left(25^{\text {th }}\right.$ February, 2005); 'V-c pay survey: Thriving v-cs net $6.1 \%$ rise in wages' $\left(20^{\text {th }}\right.$ February 2004); 'Disparity is a disgrace' ( $1^{\text {st }}$ March 2002); 'Union fury at 'shameless' v-c pay rises' (26 $6^{\text {th }}$ January, 2001); 'Pay rises for university chiefs more than double increases given to their staff' (26 $6^{\text {th }}$ January 2001).

${ }^{3}$ Organisations employing $500+$ workers in a single site or in multiple sites.
} 
comparable to that received by private sector CEOs with similar executive responsibilities (Tarbert et al, 2007). Furthermore, UK HEIs differ greatly in terms of their history, organisational structure, size and the markets they cater for (Dolton and Makepeace, 1989). One would expect CEO pay to also reflect these differences.

Despite a high level of public interest in the pay of CEOs of HEIs only a few studies on their pay determining process have been undertaken. This study adds to the literature in several respects. First, it contributes new evidence on the determination of pay of CEOs that lead and head UK higher education institutions. On a more general level it also contributes to the relatively small body of research on the determinants of CEO pay in the public sector.

Second, using a large and unique dataset it is possible to extend the period of analysis to 2006. Previous research on the determination of CEO pay covered a period up to and including the academic year 2002 (see Tarbert et al 2007; Dolton and Ma, 2003). Moreover, during the period between 2002 and 2006 the HE sector has seen radical change. For instance, over half the institutions classified as University Colleges, Arts and/or Higher Education colleges were granted independent degree awarding powers by the Privy Council and subsequently assumed 'university' status. Many of these institutions and the specific personal characteristics of their CEOs are included in this analysis.

Third, the dataset employed is more comprehensive and complete in its coverage of UK higher education institutions and the personal characteristics of their CEOs than previously employed by researchers with similar research interests. For instance, due to missing data, the number of observations used by Dolton and Ma (2003) falls from 1007 to 357 for the eight academic years of coverage when information on 291 CEOs’ personal characteristics are combined with institutional characteristics. Our dataset covers ten years and contains 1476 observations with complete information on CEOs' characteristics and the characteristics of their respective institutions between 1997 and 2006. We are therefore able to offer more representative estimates of the influence that individual CEOs' characteristics and institutional characteristics have on the CEO pay determining process in UK higher education. 
Fourth, we are able to explore the relationship between CEO performance and pay using a unique set of publicly available performance indicators. These indicators include financial performance variables but also variables that capture institutions' success in 'widening participation' in accordance with current UK government policy (DfES, 2003). Such analysis is absent in existing research and it is therefore possible to offer a novel contribution to the literature in this respect. The next section provides a brief review of the relevant literature. This is followed by a description of the key features of the data followed by a description of the methodology employed. The results are presented in the penultimate section and a summary of the conclusions is presented in the final section.

\section{Literature}

The relationship between executive pay and the factors that are assumed, a priori, to influence such rewards has received substantial attention in the academic literature and this interest has grown considerably over the last two decades. This research is almost entirely concerned with executive pay in the private sector. ${ }^{4}$ In addition to human capital theory (Mincer, 1975; Becker, 1993), three general approaches to explain CEOs' relatively high levels of pay can be identified in the literature: the principal-agent approach, tournament theory, and the theory of managerial power. A further motivation for this research is to identify which of these theories best explains the CEO pay determining process in UK higher education given data constraints.

In certain respects the pay of CEOs in UK higher education can be viewed as a principal-agent problem where it is necessary to motivate the agent to act in the principal's best interest, by designing 'optimal contracts' where executive effort is unobserved (see Mirrlees, 1976; Holmstrom, 1979; Murphy, 1985, 1986; Jensen and Zimmerman 1985; Jensen and Murphy, 1990; Gregg, et al. 1993; Conyon, et al. 1995; Conyon and Murphy, 2000; Conyon, et al. 2000). This theoretical framework points to a link between executive pay and the 'size' and 'performance' of the firm. Two major problems are encountered in applying this framework to the pay of CEOs in UK higher education. First, it is not possible to specify precisely who the principals are. It can be argued that the council, senate or governing body are the principals as

\footnotetext{
${ }^{4}$ For comprehensive reviews of the literature see Murphy (1999), Prendergast (1999), and Jensen et al. (2004).
} 
the CEO has to report to these 'committees' on institution affairs. Moreover, the CEO is also an executive member of these committees and is therefore in a position to influence decisions. In this sense, the CEO can be both principal and agent (Dolton and Ma, 2003). Second, it is often difficult to determine what exactly constitutes 'performance' in higher education (e.g. income generation, research/teaching quality, student enrolment, etc.) and indeed what elements of performance are to be attributed to CEO effort.

The second approach applies tournament theory to explain the high level of executive pay (see Lazear and Rosen, 1981; Rosen, 1986). The basic framework assumes that promotion lotteries provide the necessary incentives for high ranking executives where executive effort is again unobservable. Firms and organisations are prepared to spend large sums of money on CEO salaries and benefits to reward capability because it also serves to motivate workers at all levels in the firm to work hard for promotion. Workers are ranked according to their relative performance and winners secure the 'prize', known in advance, in terms of higher pay and the opportunity to participate in subsequent promotional tournaments. The ultimate prize is the promotion to the rank of CEO. Employees are assumed to exert effort to increase the likelihood of securing the 'prize', and the effort expended depends on the differential in pay between a high ranked position and a lower rank, the number of competitors in the lottery and the likelihood of winning (see O’Reilly, et al. 1988; Main, et al. 1993; Knoeber and Thurman, 1994). It is possible that the pay package awarded to high ranking university officers (e.g. Vice Chancellor) is influenced by the pay packages received by those in a lower ranked position (e.g. Pro Vice Chancellor) or simply by the presence of highly paid academics/staff. Moreover, we may expect that a vacant CEO position in a prestigious institution, noted for its quality in research and teaching, will attract more candidates for the post than a lower ranked HEI on the basis of these attributes. Thus the likelihood of winning the 'tournament' and securing the post in a highly ranked HEI is lower in comparison, and pay will be higher in these institutions compared to a lower ranked institution.

The third approach, the theory of managerial power, focuses on the influence that CEOs have over their own pay package. The strength of this influence will depend on their relationship with the board of directors and/or the remuneration committee 
(Main and Johnston, 1993; Main et al, 1995; Blanchard, et al. 1994; Conyon, 1997; Newman and Mozes, 1999; Bertrand and Mullainathan, 2001; Conyon, 2006; Bebchuk and Fried, 2006, 2003). There is also some evidence that the composition of the board or remuneration committee and the level of pay enjoyed by its constituent members can influence awards (Ezzamel and Watson, 2002; Forbes and Watson, 1993). However, CEOs are constrained from unfavourable rent seeking behaviour by the amount of 'outrage' a proposed compensation package is expected to generate among relevant outsiders. Such sentiments are likely to cost CEOs embarrassment and loss of reputation and will act to constrain excessive awards (Johnson et al. 1997). These considerations may influence the pay of many CEOs in UK higher education. It is possible that the composition of the senate/board of governors or remuneration committee and their relationship with the CEO could influence the remuneration package. Indeed outside pressure from government, the media and labour unions could act as a constraint on excessive pay awards. However, the data required to test this theory in the context of this paper are not publicly available.

\section{The case of CEO pay in UK higher education}

Research into the determination of CEO pay in UK higher education is very limited. ${ }^{5}$ Bainbridge and Simpson (1996), using a cross section of 64 CEOs of UK universities for the academic year 1993/94, found some evidence of university income (income from research grants and fees), the public status and the academic discipline of the CEO exerting significant effects on pay. Moreover, they found that tenure exerted a mild but significant negative effect.

Dolton and Ma (2003) using a similar formulation of the earnings function estimated the earnings relationship for CEOs of UK HEIs using a data panel covering eight academic years from 1993/1994 through 2001/02. They found evidence that CEOs' human capital variables (age, certain academic qualifications and academic and public

\footnotetext{
${ }^{5}$ There has been some empirical research on the determinants of pay of college presidents in the US. For example Ehernburg et al. (2001) found a weak link between pay and institution performance (i.e. the presidents success in securing private donations). However, they do find some evidence linking the president's tenure and experience with pay and evidence linking institution size, type and income to pay though these effects are not robust across the specifications reported. Cornell (2002) found that elite US universities do not find it difficult to recruit suitable candidates for the position of president even though they are paid significantly less and have similar skills and abilities to top corporate CEOs.
} 
honours), had a positive and significant effect on pay. They found little evidence that previous experience as a CEO influenced pay. In terms of institution characteristics they found some evidence of university type and size influencing pay. However, it should be stressed that the significance and impact of these variables on pay varied across the econometric specifications reported. They also included controls for institution performance. These included financial performance indicators and the results from the Research Assessment Exercise (RAE). They found that some of these controls had a positive and significant effect on pay. They also found some evidence that the presence of highly paid staff in an institution had a positive effect on CEO pay.

In a more recent study Tarbert et al. (2007), using CEO salary data for CEOs that led pre-1992 (old) universities and post-1992 (new) universities and a modest set of controls for university size and performance for the period 1997-2002, found only limited evidence that university performance and size had an effect on pay. However, they do detect that the presence of 'highly' paid staff (earning over $£ 50,000$ ) ${ }^{6}$ in the institution and the average pay of CEOs heading comparable higher educational institutions both have a positive effect on pay.

\section{Data}

The data employed in this paper were collected from a variety of sources that are listed in the data Appendix. The dataset contains information on 291 CEOs who led 148 UK HEIs from the academic year 1995/96 though to 2005/06. ${ }^{7}$ The definitions of the variables and their associated summary statistics are detailed in Table A1 of the appendix. Specifically, there is information on CEO pay, their individual specific characteristics, and institutional-level characteristics. The pay data and all other financial data used are adjusted to 1998 prices. As noted in the introduction, UK HEIs differ widely in many respects. For the purpose of this analysis institutions are classified into one of five broadly defined higher education sub-sectors. The majority of the sample consists of universities classified as 'old' (40.5\%) and 'new' (27.7\%).

\footnotetext{
${ }^{6}$ Whether $£ 50 \mathrm{~K}$ is indeed 'high pay' is debatable; mean academic pay over the period covered by Tarbert et al. (2007) was about £33K (ASHE (various years)).

${ }^{7}$ Institutions not included in the sample are very small specialist institution (e.g. Institute of Legal Studies, Institute of Germanic \& Romance Studies, and Conservatoire for Dance and Drama) and the private sector University of Buckingham.
} 
These are followed by institutions classified as 'other' (15.6\%) and colleges of Art, Music or Drama (12.2\%). The least represented group are those institutions classified as Medical and Business Schools (3.9\%).

Annual data on CEO pay were obtained from the Times Higher Education Supplement (THES) for the period 1996/97 through 2005/06. The salary reported includes any performance-related pay and an estimated value of benefits in kind but exclude pension contributions made by the institution. It is not possible to distinguish between the elements that make up the final pay from the information provided. The mean pay over the sample period is $£ 117,769$ in 1998 prices. We note that over the period average pay increased by about $37.4 \%$ in real terms, and this represents a $3.2 \%$ real annual increase. This increase is not evenly spread across all CEOs. Chief Executive Officers in the bottom $10^{\text {th }}$ percentile have experienced the smallest increase in real pay (29.9\%) and those in the top $90^{\text {th }}$ percentile experienced the largest $(44.2 \%)$. The sample data also reveal that CEOs of 'old' universities are paid, on average, significantly more $(£ 129,850)$ than their counterparts in 'new' universities $(£ 121,685)$. It is also interesting to note that on average the CEOs of institutions classified as an Art, Music or Drama College receive the lowest average pay $(£ 87,689)$ and the CEOs of colleges of Medical and Business Schools are amongst the highest paid $(£ 146,812)$.

Human capital variables such as age, tenure, educational background, and experience are expected to enhance the pay of the CEO, a priori. The data reveal that the average age is just over 57 and there is a distinct male dominance (88.4\%). The average length of tenure is just under six years, but for those who completed their term in office (either through retirement or resignation) it is just over eight years. The data also reveal that a large proportion of CEOs have an academic specialism in the social sciences (45.3\%) and physical sciences (29.9\%), and 68.4\% have been awarded a PhD or equivalent qualification. The sample data also reveal that $76.9 \%$ of all CEOs were externally appointed

One would expect that academic and public esteem is positively related to pay. Three qualitative dichotomous variables have been used to control for this effect: the award 
of a professorship; ${ }^{8}$ a fellowship to a Royal Society or Academy, or equivalent; and/or the award of a knighthood. Such individuals may be expected to enhance the institution's reputation, increase the potential for private sector funding opportunities, and bring with them a set of network contacts. As expected a high proportion of all CEOs, just under $86 \%$, have reached the grade of professor, about $58 \%$ are fellows of the Royal Society of Arts or Sciences, British Academy, or equivalent academic society and $14.1 \%$ have been awarded a knighthood.

The nature of CEOs' previous work experience is defined by four broad categories that describe the general nature of work the incumbent was engaged in for the ten years prior to being appointed CEO. The majority (85.3\%) have a recent career history in academia, followed by those who were formerly employed in the civil service (6.6\%), and then by those who were employed in the private sector (5.5\%).

The CEO's pay is hypothesised to be positively related to institution size and complexity. Two variables are used to capture these effects: the number of academic cost centres, and the number of full time equivalent (FTE) academic staff. On average institutions have just over fifteen cost centres, reflecting the type and nature of diverse activities undertaken within each institution. The average number of FTE academic staff is about 854 in the sample.

We include several controls to test for 'tournament' effects: the proportion of senior academic staff to all academic staff (17\%); the proportion of professors to all academic staff (8\%) and the proportion of staff paid over $£ 100,000$ per annum to all academic staff. It is hypothesised that the presence of a medical school will attract highly paid clinicians and in accordance with tournament theory will drive up the pay of the CEO. We include two controls to capture this effect: the proportion of undergraduate medical students to all undergraduate students (14.4\%) and the proportion of postgraduate medical students to all postgraduate students (10.4\%).

We expect CEOs’ pay to be positively related to university income, as a reward for sound financial management and leadership. We employ four income variables,

\footnotetext{
${ }^{8}$ It should also be noted that a professorship often carries responsibilities that can be best described as managerial e.g. Dean of School, head of a research centre/institute/department, and can also include senior administrative tasks, see Bargh et al. (2000).
} 
income from: funding council grants; tuition fees and educational grants; research grants and contracts; and sundry sources. In addition we include a variable for the proportion of overseas (non-EU) tuition fees to tuition fees and funding council grants from domestic sources. It is hypothesised that successful institutions, in terms of research and teaching, will attract a significant proportion of overseas students. We may expect CEOs to be rewarded for their success in this respect. Overseas tuition fees relative to other tuition fees and grants for teaching purposes account for $8.3 \%$ of such funds.

Performance indicators that capture research and teaching quality, the rate of undergraduate attrition and graduate employability, and indicators that capture 'widening participation' (DfES, 2003) are excluded from the primary analysis. The summary statistics and definitions for these additional variables are reported in table A2 of the Appendix. It is conceded that these variables may impact on CEO earnings but are not available for the entire sample period and moreover are not available for many of the institutions found in the Medical/Business school, colleges of Art, Music and Drama, and the 'other' HEI sub-sectors. However, they are included in a secondary analysis that uses the subset of 'new' and 'old' universities. We note that 'old' universities perform better on average than new universities in terms of their average RAE scores, 5.37 and 3.37 respectively. The drop out rate for first year students in 'old' universities (9.3\%) is, on average, lower than in 'new' universities (15.5\%). However, 'new' universities attract a higher proportion of students from lower socio economic groups (34.8\% v. 22.2\%), state schools and colleges (93.7\% v. 80.2\%), and students from areas where participation in higher education is historically low (17.4\% v. $10.6 \%)$.

\section{Methodology}

The primary theme of this paper is to estimate the relationship between CEO pay and their personal characteristics and the characteristics of the institution in which they are employed. Three econometric methodologies are employed for this purpose. First, a conventional pooled OLS regression approach is employed where observations are pooled across both time and institutions. The basic model can be expressed as: 


$$
\mathrm{W}_{\mathrm{ijt}}=\beta^{\prime} \mathbf{X}_{\mathrm{it}}+\gamma^{\prime} \mathbf{Z}_{\mathrm{jt}}+\delta \mathrm{W}_{\mathrm{jt}}+\sum_{\mathbf{t}=\mathbf{1}}^{\mathrm{T}} \varphi_{\mathbf{t}} \mathbf{D}_{\mathrm{ijt}}+\mathbf{u}_{\mathrm{ijt}}
$$

where: $\mathrm{w}_{\mathrm{ijt}}$ is the natural log of real annual pay for the $\mathrm{i}^{\mathrm{th}} \mathrm{CEO}$ in institution $\mathrm{j}$ at time $\mathrm{t}$; $\mathbf{X}_{\mathrm{it}}$ is a $\mathrm{k} \times 1$ vector of CEO specific pay determining variables, for the $\mathrm{i}^{\text {th }}$ individual (e.g. age, gender, educational background, esteem and previous work experience and training); $\mathbf{Z}_{\mathrm{jt}}$ is a $\mathrm{k} \times 1$ vector of institution specific pay determining characteristics for the $\mathrm{j}^{\text {th }}$ institution (e.g. institution type, size, hierarchical structure and income variables); $\mathrm{W}_{\mathrm{jt}}$ is a location specific pay determining condition for the $\mathrm{j}^{\text {th }}$ institution (average house prices); $\mathrm{D}$ is a set of time specific dummies introduced to capture time effects; $\beta, \gamma, \delta$ and $\varphi$ are unknown wage equation parameters; $u_{i t}$ is an error term assumed to conform with standard distribution assumptions, $\mathrm{u}_{\mathrm{it}} \sim \operatorname{iid}\left(0, \sigma^{2}\right)$.

The pooled OLS may not be the most efficient estimator to employ if there is variation either across or between individuals/institutions over time. The more efficient and consistent estimators to employ would be the fixed effects (FE) or random effects (RE) estimators. These estimators allow for unobserved heterogeneity that characterises individual CEOs and/or institutions that are assumed constant over time. They therefore allow us to control for the potential bias in the estimated coefficients associated with omitted 'unobservable' variables. In the context of this research we model the random and fixed effects at the institutional rather than the individual level using the covariates described in expression [1].

Similar formulations of expression [1] are used to explore the relationship between CEO pay in 'old' and 'new' universities and the 'performance' of the institution they run. The vector of CEO characteristics $\mathbf{X}_{\mathbf{i t}}$ is excluded from this analysis and institution performance indicators (i.e. variables capturing teaching and research quality and student participation rates) are included in the vector $\mathbf{Z}_{\mathrm{jt}}$.

\section{Empirical Results}

We now turn to the process of CEOs' pay determination. The estimates for the pooled OLS, fixed effects (FE), and random effects (RE) specifications, for the primary analysis are reported in Table 1 . The natural logarithm of real annual pay is used as 
the dependent variable in the three specifications reported. All specifications include controls for CEOs' personal characteristics, institution characteristics ${ }^{9}$ and the higher education sub-sector in which the institution operates. ${ }^{10}$ The natural logarithm of the average county level house price and a set of time dummies are also included in each specification. We first note that all three specifications fit the data reasonably well using the appropriate goodness of fit measure reported at the bottom of Table 1 . What is apparent from these models is that the significance of the included regressors is model dependent. On the basis of an F-test the FE specification is preferred to the pooled regression model. ${ }^{11}$ Similarly, on the basis of a Hausman test we reject the null of RE in favour of the FE specification. ${ }^{12}$ Thus the FE is our preferred specification and we focus our discussion on the estimated coefficients reported for this model. The pooled and RE models are presented to aid comparison with previous research.

The coefficients on a majority of the academic year dummies are well determined and are jointly significant at a conventional level. In general the point estimates suggest substantial pay inflation since the academic year 1999/2000. For instance, the point estimate for the academic year 2004/05 suggests CEO pay increased by $17.3 \%$ in real terms, on average and ceteris paribus, compared to average pay in the base year. There was a marginal decrease in the rate of increase in pay between the base year and 2005/06 (17.1\%). This particular result may be influenced by the adverse media coverage of CEOs pay during the lecturer's union industrial action in March $2006{ }^{13}$ This particular relationship is detected in all the specifications reported.

Several of the estimated coefficients for the CEOs' personal characteristics are well determined. A significant gender effect (male $=1$ ) is detected, the point estimate suggests that male CEOs, on average and ceteris paribus, are paid 8\% more than their female counterparts. This might be taken as evidence of gender inequality in this

\footnotetext{
${ }^{9}$ Non-nested J-Tests were conducted on specifications based on personal characteristics only $(\mathrm{t}=13.02$ $[0.00])$ and a specification based on the institution characteristics only $(t=9.27[0.00])$. These tests fail to reject the null of no influence of the predicted values from the alternative specification in both cases suggesting that an optimal approach is to combine both sets of variables.

${ }^{10}$ As the variables that capture the higher education sub-sector are time invariant they are excluded when estimating the FE model.

${ }^{11} \mathrm{~F}(147,1282)=3.86[0.00]$.

${ }^{12} \chi_{46}^{2}=71.07$ [0.00]. A Breusch-Pagan test for RE was also employed which also decisively rejects the null, $\chi_{1}^{2}=223.48$ [0.00] (i.e. there is no random variation in unobservables across institutions). ${ }^{13}$ See for example 'Large rises at top as pay dispute grips sector' (THES, $10^{\text {th }}$ March 2006).
} 
particular labour market, but it should be noted that female CEOs represent only about $12 \%$ of the sample. There is no evidence that CEOs' age influences pay. ${ }^{14}$ However, this particular result may be picking up a quality effect where the bidding for talent, through the award of higher pay, is not dependent on age.

The award of a $\mathrm{PhD}$ (or equivalent qualification) is found to have no significant effect on pay. This result may be considered unsurprising given that CEOs, on average, are appointed in their mid-fifties and many were awarded their PhDs in their mid to late twenties. As a consequence remuneration committees (and appointing committees) may place more weight on the academic discipline, work experience, training, and the labour market returns to a specific academic specialism than the type of educational qualification attained in determining pay. However, there is no evidence that academic discipline influences pay and as a group these variables are not jointly significant at a conventional level in the FE specification $(F=0.36$ [0.78]). This may be due to the fact that a Vice Chancellorship or equivalent is generally a late career choice and the influence of subject specialism is more likely to affect appointment than pay.

Two coefficients on the 'university attended' variables are well determined and as a group they are jointly significant at a conventional level. The largest differential in pay is found between CEOs that have been educated overseas and their Oxbridge counterparts. The point estimate suggests that those educated overseas earn about 7.5\% more, on average and ceteris paribus, than those with an Oxbridge background. However, this effect is driven by the small proportion of CEOs who have this attribute and who are amongst the highest paid in the sample. Moreover, this may reflect a global shortage of suitable individuals to fill vacancies. The coefficient on the London University control is also well determined and suggests that CEOs with this attribute are paid about 5\% more, on average and ceteris paribus, than CEOs in the base category.

Turning to variables that capture personal/academic esteem we find that the award of a professorship has a negative impact on pay. This result suggests that CEOs who

\footnotetext{
${ }^{14}$ Quadratic age terms were found to have no significant effect and were excluded from the specifications reported.
} 
hold professorships are paid about 3.5\% less, on average and ceteris paribus, than CEOs who are not professors. It is not clear why this may be but may be due to the high proportion of professors that lead low pay HEIs. For instance 76\% of CEOs that lead 'other' HEI have professorships and the equivalent figure for the heads of Art, Music or Drama Colleges is $78 \%{ }^{15}$

There is evidence that CEOs who have been employed by a public sector higher educational body are paid more than their counterparts who have a career history more firmly rooted in academia. The point estimate suggests that CEOs with this particular background are paid about 7.5\% more on average and ceteris paribus, than CEOs in the base category. We also detect a well determined coefficient on the 'industry' variable. The point estimate suggests that CEOs with private sector industrial experience are paid 8.3\% more, on average and ceteris paribus, than their counterparts in the base category. This result is in line with our priors and may reflect the need to offer high salaries to attract individuals with the necessary managerial and leadership skills from the private sector.

There is no evidence that previous experience of leading a HEI either in the capacity of a CEO or deputy CEO affects pay. In terms of the controls included to capture 'current employment' we find no evidence that the length of tenure impacts significantly on pay. ${ }^{16}$ This result is in conflict with that reported by Dolton and Ma (2003) who detect a non linear downward relationship between tenure and earnings that rises after the sixth year in post in their RE regression. The upward movement in pay, they conjecture, is driven by bonuses that accompany the expiration of a contract or a 'golden handshake'. We do find some evidence of this final payment influencing pay. The point estimate suggests that final payments to CEOs at the termination of their contract enhance earnings by just over $2 \%$, on average and ceteris paribus. There is evidence that externally appointed CEOs are paid more than their internally appointed counterparts. The point estimate suggests that externally appointed CEOs are paid $5.7 \%$ more, on average and ceteris paribus.

\footnotetext{
${ }^{15}$ The possibility that there are correlations between the professorship dummy and the previous work experience variables was explored using interaction terms. However, the results form this exercise also produced a negative coefficient. Moreover the interaction terms were found to be insignificant.

${ }^{16}$ Quadratic tenure terms were included in each specification to test for a non linear relationship. They were found to be statistically insignificant and are not included in the specifications reported.
} 
Turning our attention to institution characteristics and their influence on pay we find very few significant coefficients on the controls included to proxy institutions' size, hierarchical structure, and income. However, we do find that the proportion of undergraduate medical students to all undergraduate students has a positive and significant effect on CEO pay. These variables are included in the specifications reported in Table 1 to test for possible tournament effects. The point estimate suggests that as the proportion of medical undergraduates increases by one percentage point pay increases by just under $0.3 \%$.

The institution income variables employed include grants received from funding councils, tuition fees, sundry income and grants from research councils. These variables are included to proxy managerial performance. Specifications that included variables that proxied university size in terms of FTE undergraduates and postgraduates, and institution income variables were also estimated, although these are not reported here. These equations had a relatively high $\mathrm{R}^{2}$ but many of the estimated coefficients were not individually significant at conventional levels. This highlighted a potential multicollinearity problem within the data. Indeed the number of FTE students and institutions' income were found to be highly correlated. For example, the correlation coefficient between FTE undergraduates and funding council grants and tuition fees are 0.82 , and 0.74 respectively. To overcome this problem we divided institution income from funding councils (grants and fees) and sundry income by FTE students, and grants from research councils by FTE research staff. However, the estimated coefficients on these variables fail to reach statistical significance at conventional levels.

Average county level house price is entered into the regressions to control for regional economic conditions that impact on local living costs and the possibility that they impact on pay. A significant effect is detected at a conventional level in the FE specification. The point estimate suggests that a ten percent increase in average house prices increases pay by $1 \%$.

Performance and Pay ${ }^{17}$

\footnotetext{
${ }^{17}$ Pay change models were also estimated. The annual difference in the log of CEO pay was used as the dependent variable and the annual difference in the performance measurers were used as regressors.
} 
The estimating equations that include controls for university type, size, hierarchical structure and both financial and the 'other' performance variables that were excluded in the primary analysis are reported in Table 2. These equations are estimated for 'old' and 'new' universities for which complete data are available. As the focus is on performance and pay we exclude controls for CEOs’ personal characteristics. Again the significance of the estimated coefficients is model dependent. On the basis of an F-test ${ }^{18}$ and Hausman test ${ }^{19}$ our preferred model is the FE specification and our discussion is focused on the estimated coefficients from this specification.

We first note that the size variables employed fail to meet statistical significance at a conventional level. However, we do detect evidence of 'tournaments' affecting pay. The largest effect is associated with the presence of highly paid staff i.e. staff paid in excess of $£ 100,000$. The point estimate suggests that a one percentage point increase in the proportion of staff earning in excess of $£ 100,000$, on average and ceteris paribus, raises CEO pay by about $1.72 \%$. Similarly the presence of senior academic staff also has a positive impact on pay. The point estimate suggests that a one percentage point increase in the proportion of senior academic staff to all academic staff, on average and ceteris paribus, raises pay by about $0.1 \%$. There is evidence that an increase in the proportion of postgraduate medical students to all postgraduate students also increases pay.

In terms of the financial performance variables we note that there is a positive and significant effect detected for the coefficient on the tuition fees variable. The point estimate suggests that a ten percent increase in tuition fees raises CEO pay, on average and ceteris paribus, by about $1.6 \%$. This effect may also be picking up a size effect, where CEOs are compensated for success in increasing growth of their institution in a highly competitive higher education market. We also detect a negative relationship between overseas tuition fees and pay. The point estimate suggests that a one point increase in overseas tuition fees relative to income from funding councils (grants and tuition fees), reduces CEO pay, on average and ceteris paribus, by about

These equations were poorly defined and no inference could be drawn. Conyon et al, (1995) discusses the problems associated with models of these kinds.

${ }^{18} \mathrm{~F}=10.098[0.00]$

$\chi_{27}^{2}=71.5[0.00]$ 
0.5\%. This result may suggest that some HEIs substitute domestic for international students when facing problems in terms of its perceived 'quality' that impacts on its domestic student recruitment and therefore its income and funding.

The variables included to capture institution performance in terms of research and teaching quality, student attrition, and students' participation in higher education (or the institution's success in 'widening participation') all fail to reach statistical significance at conventional levels in the estimated specification.

\section{Conclusion}

This paper empirically examined the pay determining process for CEOs of UK higher education institutions over a ten year period using a unique panel dataset. First, the relationship between CEO pay and their personal characteristics and the characteristics of the institution they lead was estimated. Second, we modelled the relationship between CEO pay and the performance of 'old' and 'new' universities using a subset of these data. In both these analyses three model specifications were employed, a pooled OLS, and institution random and fixed effects. Model specification tests were performed and it was clear that the institution fixed effects model performs better on statistical grounds.

From the first stage of the analysis there was little evidence to suggest that institution characteristics (size, hierarchical structure and income) affect CEO pay. This particular result confirms those presented by Tarbert et al (2007), but contradicts those presented by Dolton and Ma (2003) who found some evidence that institutions' size (proxied by cost centres, staffing levels, and the size of the student body) influenced CEO pay.

We find evidence of gender bias in this particular labour market which is consistent with the findings of Dolton and Ma (2003). This result may seem surprising as we would expect there to be no significant difference between male and females as female CEOs are, a priori, self selecting. Furthermore, we would expect that high ability females would secure CEO appointment and with it a remuneration package comparable to that of males with similar attributes and responsibilities (see Lazear 
and Rosen, 1990). However, this particular effect may also be driven by the small number of low paid females (69) who tend to head low pay 'other' HEIs. Separate FE regressions were estimated for each higher education sub-sector and a gender effect was detected in each of the sub-sectors except for the 'old' university sub-sector where no significant gender differential was detected.

Those CEOs who were externally appointed are paid on average more than CEOs who are internally appointed. This result is in line with Chan (1996) who suggests that those externally appointed to senior positions within organisations are generally of superior quality in contrast to potential internal candidates. This feature will tend to drive up the pay of externally appointed CEOs, above those of their internal competitors. Murphy and Zabojnik (2003) also show that CEOs hired from the outside earn more than CEOs promoted internally. The results are also suggestive of a global shortage of suitable candidates for the post since candidates appointed from overseas are attracted to UK HEIs with the lure of a pay package that is considerably higher than those of their UK counterparts.

Chief Executive Officers that have previous work experience in industry or in governmental higher education departments/bodies are awarded favourably for the skills and knowledge that they bring to the institution in question. This fact is reflected in the sums reported as being spent on 'head hunters' employed to find suitable candidates for the top job (see for example, 'Masters of the hunt', THES $30^{\text {th }}$ July 1999). There is clear evidence of a 'golden handshake' in the form of end of contract bonuses although this is against the guidelines set by the CUC if such payments are an ‘inappropriate use of public funds’ (CUC, 2004, p.26).

From the secondary analysis we find that the presence of senior academic staff and highly paid staff in an institution has a positive impact on CEO pay as predicted by tournament theory. This confirms the results presented by Tarbert et al. (2007). However it is interesting to note that only a small proportion of CEOs (25\%) reach their position through internal promotion. There is variation across the higher subsectors. For instance, 18\% of CEOs in 'old' universities were internally promoted and for 'new' universities the figure is about 34\%. This may suggest that although 'tournaments' are detected to impact positively on CEO pay their influence differs 
across higher education sub-sectors, if internal promotion reflects success in a promotional tournament.

Moreover, we find evidence that the level of tuition fees awarded to an institution by UK funding councils positively impacts on pay. This has important public policy implications. In the academic year 1997/98 students were expected to contribute up to $£ 1000$ to the cost of their tuition. In 2006/07 top-up fees were introduced and students are now expected to contribute up to $£ 3000$ each year towards the cost of their tuition. Some universities, particularly the Russell group of universities, see the introduction of these fees as necessary to bridge government 'under-funding'. As CEO pay in higher education is influenced by tuition fees, as evidenced in this research, then we can infer that tuition fees may act as a constraint on CEO pay. This can be interpreted as an award for success in attracting students or more cynically as students funding CEOs’ pay awards.

There has also been an increasing trend for HEIs to recruit students from overseas. The results from this research suggest that as the proportion of fees received from overseas (non-EU) students rise relative to tuition fees received by domestic students there is a reduction in pay. We interpret this result as an indication of institutions that are in financial trouble and in need of additional funding from alternative sources including income from overseas (see Dolton and Ma, 2003).

There is little evidence to suggest that meeting current government policy objectives on widening participation impacts on CEO remuneration in 'old' and 'new' universities. Moreover there is also a lack of evidence to suggest that they are rewarded for the quality of teaching and research of their institutions.

We were unable to test the theory of managerial power in this labour market due to the limited availability of data. In order to do so would require detailed data on the composition and pay of the members of the remuneration committee and other stakeholders that is not available for this research, but this does provide an avenue for future research. However, the evidence presented in this paper supports the view that the human capital characteristics of the CEO and the existence of 'tournaments' in are important in determining pay in this labour market. 


\section{References}

Baimbridge, M. and Simpson, C., (1996). 'Rewards to Academia: the Remuneration of Vice Chancellors and Principals.' Applied Economics, 28, pp631-639.

Bargh, C. Bocock, J. Scott, P., and Smith, D, (2000). University Leadership. The Role of the Chief Executive. SRHE and Open University Press.

Bebchuk, L., and Fried, J., (2006) 'Pay without Performance: Overview of the Issues.' Academy of Management Perspectives, 20(1), pp5-24.

Bebchuk, L., and Fried, J., (2003) 'Executive Compensation as an Agency Problem.' Journal of Economic Perspectives, 17(3), pp71-92.

Becker, G. S. (1993), Human Capital: A Theoretical and Empirical Analysis, with Special Reference to Education. $3^{\text {rd }}$ Edn (University of Chicago Press).

Bertrand, M., and Mullainathan, S. (2001) 'Are CEOs Rewarded for Luck? The Ones Without Principals Are.' Quarterly Journal of Economics, 116(3), pp901-32.

Blanchard, O., Lopez-de-Silanes, F., and Shleifer, A. (1994) 'What do Firms do with Cash Windfalls?' Journal of Finance and Economics, 36(3), pp337-360

Chan, W. (1996), ‘Internal Recruitment versus Internal Promotion’, Journal of Labour Economics, 14(4), pp555-570. 
Committee of University Chairman (CUC) (2004), Guide for Members of Higher

Education Governing Bodies in the UK’. November 2004.

Conyon, M. (1997), 'Corporate Governance and Executive Compensation.’ International Journal of Industrial Organisations, 15(4), pp493-510.

Conyon, M. (2006), 'Executive Compensation and Incentives.'Academy of Management Perspectives, 20(1), pp25-44.

Conyon M., Gregg P., and Machin, S. (1995), 'Taking Care of Business: Executive Compensation in the United Kingdom.' Economic Journal, 105, pp704-714.

Conyon M., and Murphy, K. (2000) 'The Prince and the Pauper? CEO pay in the United States and the United Kingdom.' The Economic Journal, 110, F640-F671.

Conyon M., Peck S., Read L., and Sadler, G. (2000) 'The Structure of Executive Compensation Contracts: UK Evidence.’ Long Term Planning, 33 pp478-503.

Cornell, B. (2004) ‘Compensation and Recruiting: Private Universities Versus Private Corporations.’ Journal of Corporate Finance, 10(1), pp37- 52.

Department for Education and Skills (2003). ‘The Future of Higher Education’. Cm 5735, HMSO. 
Dolton, P. and Ma. A. (2003). 'CEO Pay in the Public Sector: The Case of Vice Chancellors in UK Universities’, Newcastle UK: Working paper, Newcastle University Discussion Papers in Economics.

Dolton, P. and Makepeace G. (1982). 'University Typology: A Contemporary Analysis.’ Higher Education Review, 13(3), pp33-47.

Ehrenberg, R., Cheslock J., and Epifantseva J. (2001), 'Paying Our Presidents: What Do Trustees Value?’ The Review of Higher Education, 25(1), pp15-37

Ezzamel, M. and Watson R. (2002) 'Pay Comparability Across and Within UK Boards: An Empirical Analysis of the Cash Pay Awards to CEO and Other Board Members.’ Journal of Management Studies, 39 pp207-232.

Farnham, D. and Jones, J. (1998). 'Who Are the Vice Chancellors and Principals in the UK? An analysis of their Professional and Social Backgrounds 1990-1997.' Higher Education Review, 30(3), pp42-58.

Forbes, W., and Watson, R. (1993), 'Managerial Remuneration and Corporate Governance: A Review of the Issues, Evidence and the Cabury Committee's Proposals.' Accounting and Business Research, 23, pp331-38

Gregg, P., Machin, S., and Szymanski, S. (1993). 'The Disappearing Relationship Between Directors' Pay and Corporate Performance.’ British Journal of Industrial Relations, 31. pp1-10. 
Holmstrom (1979) ‘Moral Hazard and Observability’ Bell Journal of Economics, 10(1), pp74-91.

Jensen, M. and Murphy, K. (1990), 'Performance Pay and Top Management Incentives.’ Journal of Political Economy, 98(2), pp225-264

Jensen, M., and Zimmerman J. (1985), 'Management Compensation and the Managerial Labor Market.’ Journal of Accounting and Economics, 7, pp3-9.

Jensen, C., Murphy, K., and Wruck, E. (2004) 'Remuneration: Where We've Been, How We Got to Here, What are the Problems, and How to Fix Them'. Harvard NOM Working Paper No. 04-28; ECGI - Finance Working Paper No. 44/2004.

Johnson, M., Porter, S. and Shackell-Dowell, M., (1997) 'Stakeholder Pressure and the Structure of Executive Compensation.' Available at SSRN: http://ssrn.com/abstract $=41780$ or DOI: $\underline{10.2139 / \text { ssrn.41780 }}$

Knoeber, R., and Thurman W. (1994) 'Testing the Theory of Tournaments: An Empirical Analysis of Broiler Production.’ Journal of Labor Economics, 12(2), pp155-179

Lazear E., and Rosen, S. (1981) 'Rank-Order Tournaments as Optimal Labor Contracts.’ Journal of Political Economy, 89 (5), pp841-864.

Lazear E., and Rosen, S. (1990) 'Male-Female Wage Differentials in Job Ladders.' Journal of Labor Economics, 8(1), ppS106-123. 
Main, B., and Johnston, J. (1993) 'Remuneration Committees and Corporate

Governance.' Accounting and Business Research, 23, pp351-362.

Main B., O’Reilly, C., and Wade. J. (1993), ‘Top Executive Pay: Tournament or Teamwork?’ Journal of Labor Economics, 11(4), pp606-628.

Main, B., O’Reilly, C., and Wade (1995), ‘The CEO, the Board of Directors, and Executive Compensation: Economic and Psychological Perspectives.’ Industrial and Corporate Change, 11, pp606-628

Mincer, J. (1974), Schooling, Experience and Earnings. New York: National Bureau of Economic Research.

Mirrlees (1976), 'The Optimal Structure of Incentives and Authority within an Organisation’, Bell Journal of Economics, 7(1), pp105-131.

Murphy, K. (1985). ‘Corporate Performance and Managerial Remuneration: An Empirical Analysis.’ Journal of Accounting and Economics, 7(1-3), pp11-42

Murphy, K. (1986). 'Incentives, Learning, and Compensation: A Theoretical and Empirical Investigation of Managerial Labor Contracts.’ Rand Journal of Economics, 17(1), pp69-76.

Murphy, K. (1999), ‘Executive Compensation’, in Orley Ashenfelter and David Card (eds.), Handbook of Labor Economics, Vol. 3, North Holland (1999). 
Murphy, K., and Zabojnik, J. (2003) 'Managerial Capital and the Market for CEOs', mimeo, University of Southern California.

Newman, H., and Mozes, H. (1999) 'Does the Composition of the Compensation Committee Influence CEO Compensation Practices? Financial Management, 28(3), pp. $41-53$

O’Reilly, C., Main, B., and Crystal, G. (1988), ‘CEO Compensation as Tournament and Social Comparison: A Tale of Two Theories.' Administrative Science Quarterly, 33, pp273-274

Prendergast, C., (1999) 'The Provision of Incentives in Firms.’ Journal of Economic Literature, 37, pp7-63.

Rosen, S. (1986). 'Prizes and Incentives in Elimination Tournaments.' American Economic Review, 76(4), pp701-715.

Tabert, H., Kaihong, T.a, and Watson, R. (2007) 'Pay Comparisons: An Analysis of UK University Chancellors Pay Awards’, University of Aberdeen Business School, Discussion Paper 2007-20. 
Table 1: CEO wage equations 1997- 2006

\begin{tabular}{|c|c|c|c|}
\hline \multirow[t]{2}{*}{ Variable } & \multirow[b]{2}{*}{ Pooled } & \multicolumn{2}{|c|}{$\underline{\text { Panel Models }}$} \\
\hline & & $\begin{array}{c}\text { Institution } \\
\text { Fixed Effects } \\
\end{array}$ & $\begin{array}{c}\text { Institution } \\
\text { Random Effects } \\
\end{array}$ \\
\hline Constant & $11.009(0.199)^{* * *}$ & $10.141(0.461)^{* * *}$ & $11.003(0.314)^{* * *}$ \\
\hline Age & $0.003(0.001)^{* * * *}$ & $0.0014(0.0017)$ & $0.0022(0.0012)^{*}$ \\
\hline Male & $0.043(0.016)^{* * *}$ & $0.080(0.022) * * *$ & $0.053(0.019)^{* * *}$ \\
\hline $\begin{array}{l}\text { Education Background } \\
\text { Doctoral Degree } \\
\text { Academic Discipline: } \\
\text { Engineering } \\
\text { Social Science } \\
\text { Arts } \\
\text { Science } \\
\text { University Attended } \\
\text { Ancient/Civic } \\
\text { London } \\
\text { 1960s/CAT } \\
\text { Overseas } \\
\text { Other } \\
\text { Oxford/Cambridge }\end{array}$ & $\begin{array}{l}0.006(0.012) \\
\\
0.015(0.015) \\
-0.020(0.010)^{* *} \\
-0.154(0.026)^{* * *} \\
f \\
\\
0.026(0.009)^{* * *} \\
0.007(0.023) \\
0.061(0.018)^{* * *} \\
0.142(0.020)^{* * *} \\
0.070(0.035)^{* *} \\
f\end{array}$ & $\begin{array}{l}0.003(0.014) \\
\\
-0.011(0.017) \\
0.005(0.015) \\
-0.011(0.022) \\
f \\
-0.007(0.013) \\
0.049(0.019)^{* * *} \\
0.023(0.032) \\
0.075(0.034)^{* *} \\
0.015(0.032) \\
f\end{array}$ & $\begin{array}{l}0.004(0.012) \\
\\
0.009(0.014) \\
-0.004(0 . .013) \\
-0.088(0.029)^{* * *} \\
f \\
\\
0.019(0.012) \\
0.024(0.024) \\
0.048(0.023)^{* *} \\
0.118(0.023)^{* * *} \\
0.040(0.046) \\
f\end{array}$ \\
\hline $\begin{array}{l}\text { Esteem and Public Honours } \\
\text { Professor } \\
\text { FRS } \\
\text { Knighthood } \\
\end{array}$ & \begin{tabular}{|l|}
$0.015(0.030)$ \\
$0.030(0.010)^{* * *}$ \\
$0.070(0.015)^{* * *}$ \\
\end{tabular} & $\begin{array}{l}-0.035(0.020)^{*} \\
0.003(0.020) \\
0.024(0.018) \\
\end{array}$ & \begin{tabular}{|l}
$-0.001(0.038)$ \\
$0.020(0.011)^{*}$ \\
$0.052(0.018)^{* * *}$
\end{tabular} \\
\hline $\begin{array}{l}\text { Career History and Training } \\
\text { Previous work experience }\end{array}$ & & & \\
\hline $\begin{array}{l}\text { Civil Service } \\
\text { Education } \\
\text { Industry } \\
\text { Academia } \\
\text { Training }\end{array}$ & $\begin{array}{l}0.055(0.017)^{* * *} \\
0.071(0.028)^{* *} \\
-0.037(0.077) \\
f\end{array}$ & $\begin{array}{l}0.013(0.024) \\
0.075(0.042)^{*} \\
0.083(0.024)^{* * *} \\
f\end{array}$ & $\begin{array}{l}0.014(0.020) \\
0.061(0.035)^{*} \\
0.017(0.079) \\
f\end{array}$ \\
\hline $\begin{array}{l}\text { Previous CEO } \\
\text { Previous deputy CEO }\end{array}$ & \begin{tabular}{|l|}
$0.068(0.014) * * *$ \\
$0.012(0.010)$
\end{tabular} & $\begin{array}{r}0.002(0.021) \\
-0.010(0.014)\end{array}$ & $\begin{array}{l}0.030(0.014)^{* *} \\
0.003(0.011)\end{array}$ \\
\hline $\begin{array}{l}\text { Current Employment } \\
\text { New Appointment } \\
\text { External Appointment } \\
\text { Tenure (years) } \\
\text { Contract Terminated } \\
\end{array}$ & \begin{tabular}{|l|}
$0.002(0.015)$ \\
$0.013(0.013)$ \\
$0.001(0.002)$ \\
$0.016(0.016)$ \\
\end{tabular} & \begin{tabular}{|l}
$-0.007(0.014)$ \\
$0.057(0.015)^{* * *}$ \\
$0.003(0.003)$ \\
$0.022(0.013)^{*}$ \\
\end{tabular} & \begin{tabular}{|l}
$-0.003(0.016)$ \\
$0.020(0.017)$ \\
$0.002(0.003)$ \\
$0.024(0.014)^{*}$ \\
\end{tabular} \\
\hline $\begin{array}{l}\text { Institution Characteristics } \\
\text { Russell/1994 Group } \\
\text { Higher Educational Sub-sector }\end{array}$ & $0.002(0.013)$ & N/A & $0.007(0.021)$ \\
\hline $\begin{array}{l}\text { Old } \\
\text { Medical/Business } \\
\text { Arts } \\
\text { Other HEI } \\
\text { New (Ex Polytechnic) } \\
\end{array}$ & \begin{tabular}{|l}
$-0.083(0.036)^{* *}$ \\
$0.043(0.079)$ \\
$-0.070(0.032)^{* *}$ \\
$-0.125(0.017)^{* * *}$ \\
$f$
\end{tabular} & $\begin{array}{l}\text { N/A } \\
\text { N/A } \\
\text { N/A } \\
\text { N/A } \\
f\end{array}$ & $\begin{array}{l}-0.052(0.044) \\
0.080(0.113) \\
-0.162(0.047)^{* * *} \\
-0.149(0.026)^{* * *} \\
f\end{array}$ \\
\hline Institution Size Variables (lag & d one year) & & \\
\hline $\begin{array}{l}\text { Merger } \\
\text { \#Cost centres } \\
\text { (ln) FTE Academic Staff }\end{array}$ & $\begin{array}{l}0.003(0.024) \\
0.007(0.001)^{* * *} \\
0.050(0.012)^{* * *}\end{array}$ & \begin{tabular}{|l|}
$0.031(0.051)$ \\
$0.0003(0.0016)$ \\
$0.019(0.026)$
\end{tabular} & $\begin{array}{l}0.023(0.029) \\
0.004(0.001)^{* * *} \\
0.059(0.014)^{* * *}\end{array}$ \\
\hline Institution Hierarchical Stru & lagged one year) & & \\
\hline $\begin{array}{l}\text { Academic Staffing Structure } \\
\text { Proportion of Senior } \\
\text { Academic Staff } \\
\text { Proportion of Professors }\end{array}$ & $\begin{array}{l}-0.045(0.046) \\
0.448(0.176)^{* *}\end{array}$ & $\begin{array}{r}0.045(0.091) \\
-0.218(0162)\end{array}$ & $\begin{array}{r}0.032(0.058) \\
-0.104(0.181)\end{array}$ \\
\hline
\end{tabular}




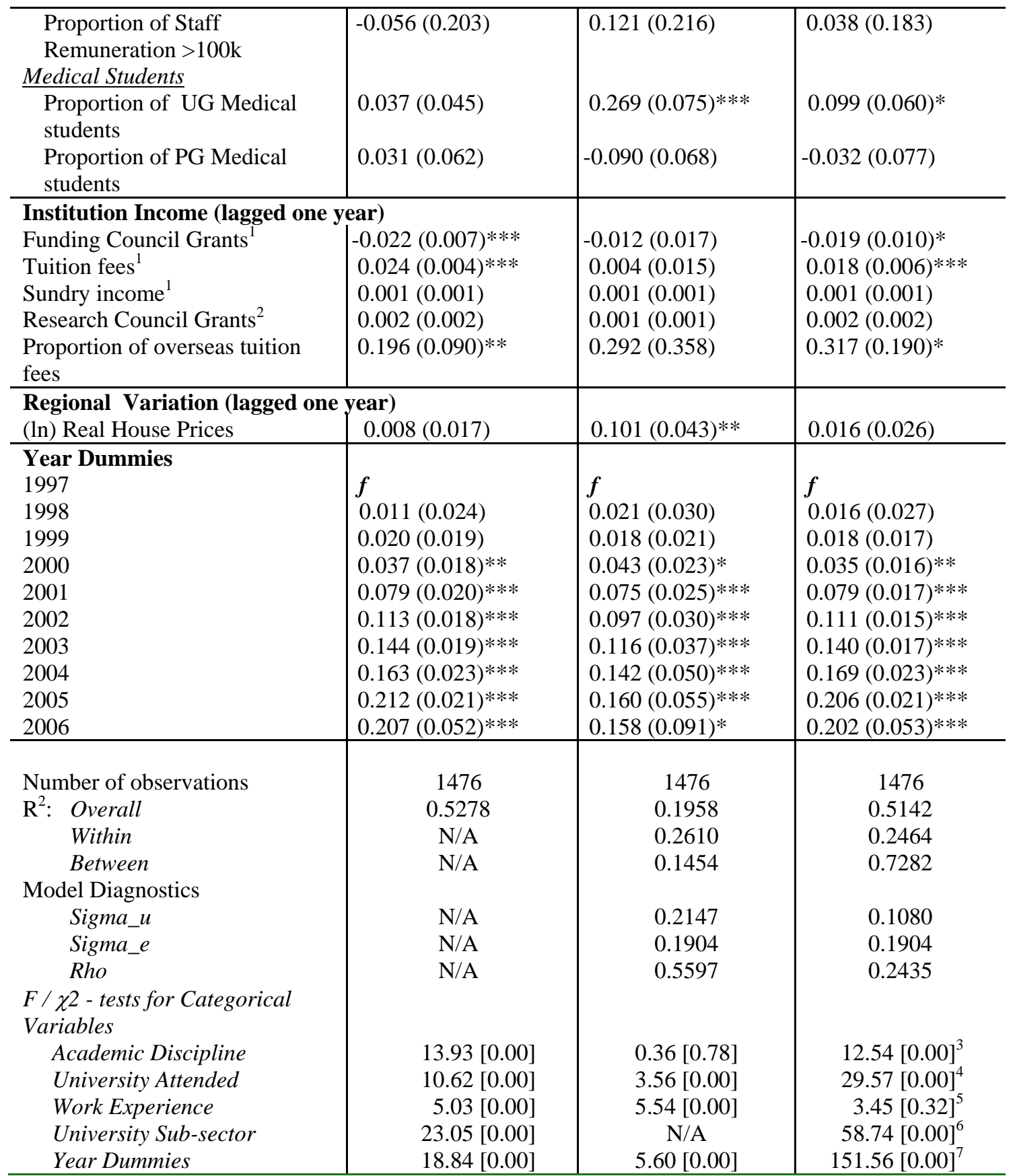

\section{Notes:}

All monetary variables are in real terms $(1998=100)$.

$* * *$ Significant at $1 \%, * *$ significant at $5 \%, *$ significant at $10 \%$.

Robust standard errors in parenthesis.

${ }^{1}$ Grants and Fees per FTE Student (£000’s)

${ }^{2}$ Research grants per FTE research staff (£000’s)

${ }^{3}$ Chi-squared statistic with 3 degree of freedom.

${ }^{4}$ Chi-squared statistic with 5 degree of freedom.

${ }^{5}$ Chi-squared statistic with 3 degree of freedom.

${ }^{6}$ Chi-squared statistic with 4 degree of freedom.

${ }^{7}$ Chi-squared statistic with 9 degree of freedom. 
Table 2: CEOs' Earnings and HEI Performance

\begin{tabular}{|c|c|c|c|}
\hline \multirow[t]{2}{*}{ Variable } & \multirow[b]{2}{*}{ Pooled } & \multicolumn{2}{|c|}{ Panel Models } \\
\hline & & $\begin{array}{c}\text { Institution } \\
\text { Fixed Effects }\end{array}$ & $\begin{array}{c}\text { Institution } \\
\text { Random Effects }\end{array}$ \\
\hline $\begin{array}{l}\text { Constant } \\
\text { Institution Characteristics }\end{array}$ & $10.461(0.235)^{* * *}$ & $9.602(0.758)^{* * *}$ & $10.003(0.302)^{* * *}$ \\
\hline $\begin{array}{l}\text { Russell/1994 Group } \\
\text { University Type }\end{array}$ & $0.026(0.017)$ & N/A & $0.035(0.036)$ \\
\hline $\begin{array}{l}\text { Pre } 1960 \text { University }^{2} \\
\text { University created in } 1960 \mathrm{~s}^{3} \\
\text { Post } 1992 \text { University }\end{array}$ & $\begin{array}{l}-0.096(0.030)^{* * *} \\
-0.016(0.030) \\
f\end{array}$ & $\begin{array}{l}\text { N/A } \\
\text { N/A } \\
f\end{array}$ & $\begin{array}{l}-0.029(0.045) \\
0.032(0.045) \\
f\end{array}$ \\
\hline \multicolumn{2}{|c|}{ Institution Size Variables (lagged one year) } & & \\
\hline $\begin{array}{l}\text { Merger } \\
\text { \#Cost centres } \\
\text { (ln) FTE Academic Staff }\end{array}$ & \begin{tabular}{|r|}
$0.044(0.027)$ \\
$-0.002(0.002)$ \\
$-0.030(0.032)$
\end{tabular} & $\begin{array}{l}0.008(0.027) \\
0.001(0.003) \\
0.018(0.027)\end{array}$ & \begin{tabular}{|r|}
$0.008(0.024)$ \\
$-0.001(0.002)$ \\
$0.007(0.027)$
\end{tabular} \\
\hline \multicolumn{4}{|c|}{ Institution Hierarchical Structure (lagged one year) } \\
\hline $\begin{array}{l}\text { Academic Staffing Structure } \\
\text { Proportion of Senior } \\
\text { Academic Staff }^{4} \\
\text { Proportion of Professors } \\
\text { Proportion of Staff } \\
\text { Remuneration }>100 \mathrm{k} \\
\text { Medical Students }\end{array}$ & $\begin{array}{l}-0.119(0.045)^{* * *} \\
0.404(0.181)^{* *} \\
3.667(1.043)^{* * *}\end{array}$ & $\begin{array}{l}0.104(0.064)^{*} \\
0.018(0157) \\
1.719(0.903)^{* *}\end{array}$ & $\begin{array}{l}0.043(0.057) \\
-0.099(0.150) \\
2.243(0.732)^{* * *}\end{array}$ \\
\hline $\begin{array}{l}\text { Proportion of UG Medical } \\
\text { students } \\
\text { Proportion of PG Medical } \\
\text { students }\end{array}$ & $\begin{array}{l}0.033(0.074) \\
0.284(0.085)^{* * *}\end{array}$ & $\begin{array}{l}-0.050(0.126) \\
0.183(0.112)^{*}\end{array}$ & $\begin{array}{l}-0.016(0.101) \\
0.255(0.098)\end{array}$ \\
\hline \multicolumn{4}{|c|}{$\begin{array}{l}\text { Performance Variables (lagged one year) } \\
\text { University Income }\end{array}$} \\
\hline $\begin{array}{l}\text { (ln) Funding Council Grants } \\
\text { (ln) Tuition fees } \\
\text { (ln) Sundry income } \\
\text { (ln) Research Council Grants } \\
\text { Overseas tuition fees (£000’s) } \\
\text { Research and Teaching Quality }\end{array}$ & $\begin{array}{l}0.085(0.043)^{* *} \\
0.051(0.025)^{* *} \\
0.012(0.015) \\
0.002(0.002) \\
-0.001(0.156)\end{array}$ & $\begin{array}{l}0.030(0.067) \\
0.158(0.044)^{* * *} \\
0.016(0.025) \\
-0.012(0.017) \\
-0.491(0.192)^{* *}\end{array}$ & $\begin{array}{l}0.023(0.050) \\
0.094(0.033)^{* * *} \\
0.012(0.201) \\
-0.005(0.014) \\
-0.240(0.176)\end{array}$ \\
\hline RAE Score & $0.006(0.156)$ & $0.001(0.018)$ & $0.003(0.016)$ \\
\hline Teaching Assessment Score & $-0.003(0.007)$ & $-0.003(0.009)$ & $-0.003(0.007)$ \\
\hline Student Attrition Rate & $-0.521(0.168) * * *$ & $-0.220(0.218)$ & $-0.260(0.197)$ \\
\hline $\begin{array}{l}\text { Graduate Unemployment Rate } \\
\text { Student Participation Rates }\end{array}$ & $-0.016(0.224)$ & $0.277(0.225)$ & $0.254(0.212)$ \\
\hline$\overline{\text { Low socio-economic group }}$ & $0.310(0.160)^{* *}$ & $-0.144(0.158)$ & $-0.045(0.149)$ \\
\hline Low participating Area & $0.162(0.103)$ & $-0.152(0.290)$ & $0.089(0.189)$ \\
\hline Comprehensive Schools & $-0.395(0.101) * * *$ & $0.079(0.257)$ & $-0.191(0.185)$ \\
\hline Year Dummies & & & \\
\hline 1999 & $f$ & $f$ & $f$ \\
\hline 2000 & $0.020(0.018)$ & $0.036(0.018)^{* *}$ & $0.031(0.016)^{*}$ \\
\hline 2001 & $0.086(0.020) * * *$ & $0.100(0.019) * * *$ & $0.095(0.017)^{* * *}$ \\
\hline 2002 & $0.097(0.024)^{* * *}$ & $0.117(0.028)^{* * *}$ & $0.109(0.025)^{* *}$ \\
\hline 2003 & $0.132(0.026) * * *$ & $0.150(0.030)^{* * *}$ & $0.145(0.026)^{* * *}$ \\
\hline 2004 & $0.144(0.027)^{* * *}$ & $0.186(0.032)^{* * *}$ & $0.178(0.029)^{* * *}$ \\
\hline 2005 & $0.180(0.026)^{* * *}$ & $0.224(0.034) * * *$ & $0.217(0.029) * * *$ \\
\hline 2006 & $0.195(0.026)^{* * *}$ & $0.252(0.036)^{* * *}$ & $0.242(0.030)^{* * *}$ \\
\hline $\begin{array}{l}\text { Number of observations } \\
\mathrm{R}^{2}: \text { Overall } \\
\text { Within } \\
\text { Between }\end{array}$ & $\begin{array}{c}752 \\
0.5625 \\
\text { N/A } \\
\text { N/A }\end{array}$ & $\begin{array}{c}752 \\
0.4302 \\
0.6232 \\
0.3088\end{array}$ & $\begin{array}{c}752 \\
0.5332 \\
0.6182 \\
0.4590\end{array}$ \\
\hline
\end{tabular}


Model Diagnostics

Sigma_u

Sigma_e

Rho

$F / \chi^{2}$ - tests for Categorical

Variables

University Type

Year Dummies

\begin{tabular}{l|c|r} 
& & \\
N/A & 0.1207 & 0.0971 \\
N/A & 0.0837 & 0.0837 \\
N/A & 0.6754 & 0.5734 \\
& & \\
$14.68[0.00]$ & N/A & $3.81[0.15]$ \\
$11.03[0.00]$ & $11.35[0.00]$ & $112.72[0.00]$
\end{tabular}

Notes:

*** significant at $1 \%$, ** significant at $5 \%, *$ significant at $10 \%$. Robust standard errors in parenthesis.

${ }^{1}$ See table A3 for definition of performance variables.

${ }^{2}$ Universities defined as Oxbridge, Ancient, Civic, and London universities.

${ }^{3}$ Universities created in the 1960s as a result of the Robbins Report (1963).

${ }^{4}$ Universities classified as ex-polytechnics 


\section{Appendix: Data sources}

Annual Survey of Hours and Earnings (ASHE) (various years), Pay Data for academics, CEOs and Senior Executives. Accessed at http://www.statistics.gov.uk/STATBASE/Product.asp?vlnk=13101

Halifax House Price Data (average UK county level house price). Accessed at http://www.hbosplc.com/economy/HistoricalDataSpreadsheet.asp

Higher Education Performance Indicators.

Accessed at http://www.hefce.ac.uk/learning/perfind/default.asp for 1996/97 to 2001/02 and at www.hesa.ac.uk/pi/ for 2002/03 to 2004/05

Higher Education Statistical Agency, (1998-2006). Reference Volume: STUDENTS in Higher Education Institutions. HESA.

Higher Education Statistical Agency, (1998-2006). Reference Volume: RESOURCES of Higher Education Institutions, HESA.

Higher Education Statistical Agency (1998-2006). Destinations of Leavers from Higher Education. HESA

International Who’s Who (various years), Europa Publications Limited.

Quality Assessment Exercise Results. Accessed at http://www.qaa.ac.uk/

Research Assessment Exercise Results. Accessed at http://www.hero.ac.uk/rae/

Retail Price Index. Data accessed at

http://www.statistics.gov.uk/statbase/TSDdownload2.asp

Times Higher Education Supplement (THES). Vice Chancellors’ Salary Data accessed at http://www.thes.co.uk/statistics/

Who’s Who (1997-2006). An Annual Biography, A \& C Black, London

Who's Who in British Art (various years). Hilmarton Manor Press

Who's Who (various years), Vice-Chancellors, Presidents, Principals, Rectors, The Association of Commonwealth Universities (ACU). 


\section{Appendix}

Table A1: Descriptive Statistics and Definition of Variables

\begin{tabular}{|c|c|c|}
\hline Variable $^{1}$ & $\begin{array}{r}\text { Mean (All } \\
\text { HEIs) }\end{array}$ & Definition of variable \\
\hline Annual Pay $£(1998=100)$ & $\begin{array}{r}117768.700 \\
(31326.31) \\
\end{array}$ & Natural log of CEO real annual salary $(1998=100)$. \\
\hline \multicolumn{3}{|c|}{ CEOs' PERSONAL CHARACTERITICS, 1996/97 - 2005/06 } \\
\hline \multicolumn{3}{|l|}{ General Characteristics } \\
\hline Male & 0.884 & $=1$ if Male, $0=$ Female \\
\hline Age & $\begin{array}{r}57.148 \\
(4.520)\end{array}$ & Age in years (year of observation minus year of birth). \\
\hline \multicolumn{3}{|l|}{ Educational Background } \\
\hline $\begin{array}{l}\text { Doctoral Degree } \\
\text { Academic Discipline- }\end{array}$ & 0.684 & Holds a $\mathrm{PhD}$ or equivalent (e.g. MD, DSci) \\
\hline Engineering & 0.102 & $\begin{array}{l}\text { Engineer (or related disciplines e.g. urban planner or computer } \\
\text { technologist). }\end{array}$ \\
\hline Social Science & 0.453 & $\begin{array}{l}\text { Social scientist (historian, philosopher, sociologist, economist } \\
\text { (or from business/finance). lawyer. educationalist). }\end{array}$ \\
\hline Arts & 0.146 & $\begin{array}{l}\text { Fine/modern artist, musician, dramatist, linguist, language } \\
\text { scholar. }\end{array}$ \\
\hline Science & 0.299 & $\begin{array}{l}\text { Biologist, chemist, physicist, geologist, mathematician } \\
\text { /statistician or with background in medical/ veterinary related } \\
\text { disciplines. }\end{array}$ \\
\hline \multicolumn{3}{|l|}{ University Attended } \\
\hline Ancient/Civic & 0.351 & $\begin{array}{l}\text { Received highest degree from either an ancient (medieval) } \\
\text { university or a civic 'red brick' university (i.e. universities } \\
\text { established in late 19th Century to late1950s). }\end{array}$ \\
\hline London & 0.175 & Received highest degree from a London University College. \\
\hline 1960s/CAT & 0.072 & $\begin{array}{l}\text { Received highest degree from a university created in 1960s or } \\
\text { from a former College of Advanced Technology (CAT) }\end{array}$ \\
\hline Overseas university & 0.038 & Received highest degree from a foreign university, \\
\hline Other HE Institution & 0.069 & $\begin{array}{l}\text { Received highest degree from a former polytechnic, art } \\
\text { college, teacher training institution etc (also includes the Open } \\
\text { University). }\end{array}$ \\
\hline Oxford or Cambridge & 0.295 & Received highest degree from an Oxford/Cambridge College. \\
\hline \multicolumn{3}{|l|}{ Personal Esteem } \\
\hline Professor & 0.857 & Holds a professorship at time of observation \\
\hline Fellow of a Royal Society/Academy & 0.579 & Awarded fellowship of Royal Society or British academy \\
\hline Knighthood & 0.141 & Knighted at time of observation \\
\hline \multicolumn{3}{|l|}{ Career History and Training } \\
\hline \multicolumn{3}{|l|}{ Previous work experience } \\
\hline Civil Servant & 0.066 & $\begin{array}{l}\text { Previously employed by civil service (excl. Dept. of } \\
\text { Education) }\end{array}$ \\
\hline Education & 0.026 & $\begin{array}{l}\text { Previously employed by official public education body e.g. } \\
\text { DfES, HEFC, QCA etc. }\end{array}$ \\
\hline Industry & 0.055 & $\begin{array}{l}\text { Previously employed in the private sector with managerial } \\
\text { and/or research responsibility. }\end{array}$ \\
\hline Academia & 0.853 & $\begin{array}{l}\text { Previously employed in the HE sector as lecturer, senior } \\
\text { lecturer, or professor. }\end{array}$ \\
\hline Previous CEO & 0.121 & $\begin{array}{l}\text { Previously appointed as a Vice Chancellor, Principal, Rector; } \\
\text { Director, Provosts or equivalent in another HE institution. }\end{array}$ \\
\hline Previous deputy CEO & 0.387 & $\begin{array}{l}\text { Previously appointed as a Pro Vice Chancellors, Assistant } \\
\text { Principal, Deputy Director, or equivalent. }\end{array}$ \\
\hline Externally Appointed & 0.769 & Externally appointed to current post. \\
\hline Tenure (years in post) & $\begin{array}{r}5.814 \\
(3.854)\end{array}$ & $\begin{array}{l}\text { Years in current post (year of observation minus year of } \\
\text { appointment). }\end{array}$ \\
\hline Contract Terminated & 0.100 & Contract expired through resignation or retirement. \\
\hline
\end{tabular}




\begin{tabular}{|c|c|c|}
\hline Variable $^{1}$ & $\begin{array}{r}\text { Mean (All } \\
\text { HEIs) }\end{array}$ & Definition of variable \\
\hline \multicolumn{3}{|c|}{ Institution Characteristics 1995/96 - 2004/05 } \\
\hline Russell/1994 Group & 0.250 & $\begin{array}{l}\text { Member of Russell group of universities or a member of the } \\
1994 \text { group of universities in year of observation. }\end{array}$ \\
\hline \multicolumn{3}{|l|}{ HEI Sub Sector } \\
\hline & 0.405 & $\begin{array}{l}\text { Includes: Oxbridge, Ancient and Civic Universities, London } \\
\text { University Colleges (excl. medical colleges/schools), } \\
\text { universities created in the 1960s and former CATs. }\end{array}$ \\
\hline Medical and Business Schools & 0.039 & $\begin{array}{l}\text { Institution engages predominantly in medical/business } \\
\text { research or related medical/business activities }\end{array}$ \\
\hline Colleges of Art, Music or Drama & 0.122 & Art or performing arts college (including music and dance). \\
\hline Other HEIs & 0.156 & $\begin{array}{l}\text { Includes agricultural, teacher training colleges, and university } \\
\text { colleges and other HE institutions }\end{array}$ \\
\hline New & 0.277 & Former polytechnics \\
\hline \multicolumn{3}{|l|}{$\underline{\underline{\text { Size }}}$} \\
\hline Number of Cost Centres & $\begin{array}{l}15.655 \\
(8.188)\end{array}$ & $\begin{array}{l}\text { Number of academic and administrative cost centres in year of } \\
\text { observation. }\end{array}$ \\
\hline Number of Academic Staff (FTE) & $\begin{array}{r}854.733 \\
(803.099) \\
\end{array}$ & $\begin{array}{l}\text { Total number of FTE academic staff including professors, } \\
\text { readers, senior lecturers, lecturers, and researchers. }\end{array}$ \\
\hline \multicolumn{3}{|l|}{ Hierarchical Structure } \\
\hline \multicolumn{3}{|l|}{$\overline{\text { Academic Staffing Structure }}$} \\
\hline $\begin{array}{l}\text { Proportion of Senior Academic } \\
\text { Staff }\end{array}$ & 0.171 & Total FTE senior academic staff to all FTE academic staff \\
\hline Proportion of Professors & 0.080 & Total FTE professorial staff to all FTE academic staff \\
\hline $\begin{array}{l}\text { Proportion of Staff Remunerated > } \\
100 \mathrm{k}\end{array}$ & 0.006 & $\begin{array}{l}\text { Total FTE staff (academic/non academic, excl CEO) } \\
\text { remunerated } £ 100,000 \text { per annum or more to all FTE academic } \\
\text { staff }\end{array}$ \\
\hline \multicolumn{3}{|l|}{ Medical Students } \\
\hline $\begin{array}{l}\text { Proportion of UG Medical } \\
\text { students }\end{array}$ & 0.144 & $\begin{array}{l}\text { Total FTE undergraduate medical and veterinary students } \\
\text { (including those on medically related HE courses (e.g. } \\
\text { dentistry and physiotherapy) to all FTE undergraduates. }\end{array}$ \\
\hline $\begin{array}{l}\text { Proportion of PG Medical } \\
\text { students }\end{array}$ & 0.104 & $\begin{array}{l}\text { Total number of FTE postgraduate medical and veterinary } \\
\text { students (including those on medically related HE courses (e.g. } \\
\text { dentistry and physiotherapy) to all FTE postgraduates. }\end{array}$ \\
\hline \multicolumn{3}{|l|}{ Income (E000’s) 1998=100 } \\
\hline Funding Council Grants & $\begin{array}{r}33068.009 \\
(27023.564)\end{array}$ & $\begin{array}{l}\text { Grants from all UK funding councils, and include block grants } \\
\text { for teaching and research, and capital grants. }\end{array}$ \\
\hline $\begin{array}{l}\text { Tuition fees \& education grants \& } \\
\text { contracts }\end{array}$ & $\begin{array}{r}19955.538 \\
(15819.637)\end{array}$ & $\begin{array}{l}\text { Fees for full-time/part-time, degree and sandwich degree, } \\
\text { diploma and other HE credit-bearing and non credit-bearing } \\
\text { courses for UK and non-UK domiciled students. }\end{array}$ \\
\hline Sundry income & $\begin{array}{r}17731.788 \\
(510.826)\end{array}$ & $\begin{array}{l}\text { Income from services (e.g. consultancies, external course } \\
\text { validation, and residential and catering services etc). }\end{array}$ \\
\hline Research grants \& contracts & $\begin{array}{r}13365.619 \\
(24964.089)\end{array}$ & $\begin{array}{l}\text { Income from externally sponsored research, and income from } \\
\text { research councils and non-UK sources. }\end{array}$ \\
\hline Proportion of Overseas fees & $\begin{array}{r}0.083 \\
(0.071)\end{array}$ & $\begin{array}{l}\text { Overseas tuition fees to total income from UK funding council } \\
\text { grants and tuition fees (as defined above). }\end{array}$ \\
\hline Real Regional House Prices & $\begin{array}{r}115604.9 \\
(52726.3) \\
\end{array}$ & $\begin{array}{l}\text { Natural log of real average county level house prices (Halifax } \\
\text { House Price Index, Halifax PLC) in year of observation }\end{array}$ \\
\hline Numb & 14 & \\
\hline Number of Vice Chance & 2 & \\
\hline Number of Institutions & 148 & \\
\hline
\end{tabular}

Notes to Table:.

${ }^{1}$ Standard deviation given in parenthesis for continuous variables. All other variables are either dummy or categorical variables. 
Table A2: Descriptive Statistics: Performance Variables for Old and New Universities 1997/98 - 2004/05

\begin{tabular}{|c|c|c|c|c|}
\hline Variables $^{1}$ & Both HEIs & $\begin{array}{r}\text { Old } \\
\text { Universities }\end{array}$ & $\begin{array}{r}\text { New } \\
\text { Universities }\end{array}$ & $\begin{array}{l}\text { z-score } \\
\text { /t-stat }^{2}\end{array}$ \\
\hline RAE score & $\begin{array}{r}4.539 \\
(1.198)\end{array}$ & $\begin{array}{r}5.369 \\
(0.643)\end{array}$ & $\begin{array}{r}3.369 \\
(0.732)\end{array}$ & 22.698 \\
\hline Teaching Assessment Score & $\begin{array}{r}20.838 \\
(1.028)\end{array}$ & $\begin{array}{r}21.212 \\
(0.932)\end{array}$ & $\begin{array}{r}20.311 \\
(0.924)\end{array}$ & 13.127 \\
\hline Student drop-out rate & 0.119 & 0.093 & 0.155 & -2.589 \\
\hline Graduate Unemployment rate & 0.098 & 0.096 & 0.099 & 0.091 \\
\hline \multicolumn{5}{|l|}{ Widening Participation ${ }^{3}$ : } \\
\hline Proportion of student from lower social class & 0.274 & 0.222 & 0.348 & -5.226 \\
\hline $\begin{array}{l}\text { Proportion of students form low participation } \\
\text { areas }\end{array}$ & 0.134 & 0.106 & 0.174 & -3.816 \\
\hline Proportion of students from state schools & 0.858 & 0.802 & 0.937 & -2.695 \\
\hline Number of Observations & 752 & 440 & 312 & \\
\hline
\end{tabular}

Notes to Table: Standard deviation given in parenthesis below the relevant statistic.

${ }^{1}$ See Table A3 for definition of variables.

${ }^{2} \mathrm{z}$-scores are used to test the differences in proportions between old and new Universities, and t-tests are used to test the differences in means. The relevant critical value at 0.05 level for a two tailed test is \pm 1.96 .

${ }^{3}$ Proportion of young full-time including students on foundation degree, HND, HNC and similar courses, as well as first degree students. 


\section{Table A3: Definitions of Performance Variables}

\begin{tabular}{|c|c|}
\hline \multicolumn{2}{|c|}{ Research and Teaching Quality } \\
\hline RAE Score & $\begin{array}{l}\text { Average institution research assessment exercise score per active researcher. } \\
\text { Calculated by multiplying the scores (graded from } 1 \text { to 7) by the numbers of } \\
\text { researchers in departments, summing this across all departments in an } \\
\text { institution, and dividing by the total number of researchers of the institution. } \\
\text { Scores are calculated for } 1996 \text { and } 2001\end{array}$ \\
\hline Teaching Assessment Score & $\begin{array}{l}\text { Teaching Assessment Scores are based on mean of all TQA subject scores } \\
\text { across the institution as published by the funding councils. Scores are } \\
\text { reported out of a possible maximum of } 24 \text {, in year of observation. }\end{array}$ \\
\hline Student Attrition Rate & $\begin{array}{l}\text { Proportion of full-time first year degree students who have withdrawn from } \\
\text { the institution during first year of study, whose destination are known, and are } \\
\text { not in any form of employment or study in year of observation. }\end{array}$ \\
\hline $\begin{array}{l}\text { Graduate Unemployment } \\
\text { Rate }\end{array}$ & $\begin{array}{l}\text { Proportion of known student destinations one year after completion of first } \\
\text { degree and represents those students not in full time or part time employment } \\
\text { or study }\end{array}$ \\
\hline $\begin{array}{l}\text { First Year Student } \\
\text { Participation Rates } \\
\end{array}$ & $\begin{array}{l}\text { These variables are measured in terms of percentage points above or below } \\
\text { the institution's benchmark. The benchmark is calculated as a sector average } \\
\text { which is then adjusted for subject of study, qualifications on entry, age on } \\
\text { entry and region. }\end{array}$ \\
\hline Low socio-economic group & $\begin{array}{l}\text { Students classified as belonging to a low socio-economic group are those } \\
\text { whose parents fall into the following occupational classes: (4) small } \\
\text { employers and own account workers; (5) lower supervisory and technical } \\
\text { occupations; (6) Semi-routine occupations; (7) Routine occupations and extra } \\
\text { classification for unemployment (8) is also used in defining this group. The } \\
\text { proportion is calculated as the number of students with this attribute to all } \\
\text { first year enrolments in the year of observation }\end{array}$ \\
\hline Low participating Area & $\begin{array}{l}\text { Areas for which the participation rate is less than two-thirds of the UK } \\
\text { average rate are defined as low-participation neighbourhoods. Students are } \\
\text { allocated to these neighbourhoods on the basis of their postcodes The } \\
\text { proportion is calculated as the number of students with this attribute to all } \\
\text { first year enrolments in the year of observation }\end{array}$ \\
\hline Comprehensive Schools & $\begin{array}{l}\text { Students from comprehensive schools. The proportion is calculated as the } \\
\text { number of students with this attribute to all first year enrolments in the year } \\
\text { of observation }\end{array}$ \\
\hline
\end{tabular}

